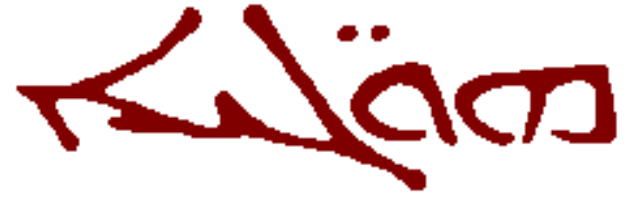

HugOYE

JOURNAL OF SYRIAC STUDIES

A Publication of Beth Mardutho: The Syriac Institute 



\title{
A SIXTEENTH-CENTURY BATRASHIL IN THE METROPOLITAN MUSEUM OF ART
}

JENNIFER L. BALL

CITY UNIVERSITY OF NEW YORK

\begin{abstract}
This paper, through an analysis of the iconography, style and use of the sixteenth-century bishop's stole and its inscription, seeks to elucidate the post-medieval history of liturgical vestments in the Syriac Orthodox church, where little research has been done. The stole will be set firmly within Syriac Orthodox art, using earlier manuscript illumination. It also illustrates ties between the Syriac Orthodox Church and the Coptic and Nubian churches. The object adds to the known history of the Mar Musa al-Habashi monastery, with which the owner of the stole was affiliated. It also furthers our limited evidence on patron-artist relationships and women artists in Islam, as the inscription tells us some information about the embroiderer.
\end{abstract}

A unique example of a medieval Syrian liturgical stole, a batrashil, is currently housed in the Islamic Department of New York's Metropolitan Museum of Art. ${ }^{1}$ While the object entered the

${ }^{1}$ My thanks to Dr. Helen Evans, Curator of Medieval Art, at the Metropolitan for first introducing me to this object, and along with Dr. 
collection in 1914, bought from a Syrian antiquities dealer who ran a New York gallery, ${ }^{2}$ the object and its important inscription, written in Arabic and Syriac, were not fully understood until recently. ${ }^{3}$ (Figs. 1-2) The batrashils inscription indicates that it was made for a Bishop Athanasius Abraham Yaghmur of Nebek in 1534/35 CE who was a scribe in the scriptorium at the monastery of Mar Musa al-Habashi in Syria. The inscription tells us about the artist, and sheds some light on the late history of the monastery with which the bishop was associated, as well as the relationship between patron and artist in sixteenth-century Syria.

\section{DESCRIPTION}

The batrashil, heavily embroidered in blue silk, measures fifty-five inches in length and almost eight inches in width. It fit over the head, through a snug rectangular hole, and fell down over the chest and back. The front of the stole displays the following nine Gospel scenes in small squares, each labeled above in Syriac: the Pentecost, Ascension of Christ, Resurrection, Crucifixion, Entry into Jerusalem, Presentation at the Temple, Baptism, Nativity, and Annunciation. (Fig. 1) The strips that fold over the shoulders bear ornate crosses in the front and two smaller crosses on the back, which lead to five panels on the back. (Fig. 2) The four Evangelists are represented along with an ornate cross, mounted on a stepped platform in the center panel.

The piece survives in very good condition with little fading, suggesting that it was treated as a precious object at the time of its

Stefano Carboni, Curator of Islamic Art, allowing me access to work on it. Thanks also to Dr. Evans and Dr. George Kiraz for their help in facilitating its publication.

${ }^{2}$ G. Beilouny came to New York in 1912 and began selling Egyptian, Greek, Roman, Persian, and Ancient Near Eastern objects from his Madison Avenue gallery. He made regular buying trips to Aleppo until the beginning of World War I, when he came back to New York for five years, before selling off his collection in 1919 and returning to Syria. G. Beilouny, A Remarkable Collection of Ancient Works of Art, (New York: 1919), 5.

${ }^{3}$ I had much help with both the Arabic and the Syriac: Professor Kathleen McVey of the Princeton Theological Seminary, Dr. George Kiraz Editor of Hugoye, Dr. Stefano Carboni of the Metropolitan Museum of Art, and Professor Irfan Shahid of Georgetown University. 
making and stored carefully. The majority of wear is found on the edges, rendering the inscription only partly legible in places. Several cuts were made and then re-sewn to prolong the life of the garment: both sides of the shoulder panels have cuts where it most likely wore from robing and disrobing; there are also cuts at the bottom edge of the garment which must have frayed from use. Metropolitan Museum of Art conservator, Nobuko Kajitani, restored the piece in the 1970s, shoring up the silk backing with new linen visible in dark blue in spots where the original medium blue silk is completely gone.

The figures are animated yet simply embroidered. They all stare forward with facial features outlined in black thread; a continuous line of stitches forms the nose and brow, and beards are made with a mass of black threads sewn into a triangle on the chin. In crowd scenes such as the Entry into Jerusalem panel (Fig. 3) and the Pentecost (Fig. 4), the men are stacked atop each other to illustrate receding space. The garments worn by the figures, especially the Evangelists, form cape-like tents, decorated with zigzags and striping. (Fig. 5) The garments do not suggest actual garments nor do they contain folds to hint at the bodies beneath them.

A cartoon-like action breaks up the rigidity of the strict frontal poses in many scenes. The angels in both Christ's resurrection and ascension (Fig. 6) flutter around Christ with their wings curving wildly around him. The witnesses in these panels crane their necks with their mouths agape as they behold Christ. In the Annunciation panel, Gabriel takes Mary by surprise as her hands are raised in fright, his colorful wings still beating. (Fig. 7) Christ's donkey prods his way into the crowd around the gates of Jerusalem (notably absent from the background) nudging the tiny people who lay olive branches at his feet. (Fig. 3)

Each scene contains only the necessary figures with little, if any, background. The figures stand in saturated blue silk space. The embroiderer stitched the figures in gold and yellow thread with orange, blue, and red touches, mostly in the form of small crosses on holy figures and objects. Metallic wire threads, now tarnished, would have made the figures shimmer within a candlelit church.

\section{ICONOGRAPHY}

The iconographical program of the batrashil is distinct and no Syrian vestments of the period survive for comparison. No 
sixteenth-century Armenian or Coptic vestments remain for comparison either. Some Byzantine ecclesiastical garments of the sixteenth-century survive but they follow stylistic trends of Western Europe, especially Italian art, and do not serve well for stylistic comparison.

Even widening our scope to other Syriac Orthodox objects of the sixteenth century we find no other works to represent this period. The closest Syrian parallels can be found in manuscript illumination of the late medieval period; these paintings typically contain liturgical feast scenes, the same subject matter found on the batrashil. Some of the surviving manuscripts predate the Metropolitan's stole by as many as four centuries, which is problematic for a direct comparison. However, the many similarities, both stylistic and iconographic, between the late Medieval Syriac Orthodox illuminations and the batrashil demonstrate a continuity within liturgical art that bridges the late medieval with the post-medieval period. Furthermore, this stole was made for a bishop at a well-known scriptorium, making manuscript illuminations a likely source for the embroiderer.

Beginning with the crosses found around the shoulder bands and back panel of the batrashil, each scene will be examined for iconographical and stylistic parallels within the corpus of Syriac Orthodox manuscripts. (figs. 1, 2 and 4) The crosses are ornate and have three distinct forms. The crosses on the front of the shoulders have curved ends and additional smaller crosses protruding from the top and bottom. The back shoulders contain two geometric crosses with small crosses superimposed over a square, with a smaller square in the center. A Latin-style double cross, with two horizontal bars, rises off a set of stairs. Each end of the cross forms another cross, and the embroiderer stitched small crosses within these. A red cross floats above the main one and the stairs are decorated with four additional crosses.

The Triumphal Cross motif-a cross mounted on a stepped platform-is in keeping with Byzantine tradition (Fig. 2), representing the cross erected by Emperor Theodosius II at Golgotha in 420 CE. It was also used in Byzantine coinage, which is often cited as the source for such crosses in Syriac Orthodox 
art. ${ }^{4}$ However, Syriac Orthodox manuscripts typically contain multiple examples of crosses, incorporating the triumphal variety as well as other forms; often an entire carpet page is devoted to such imagery. Four examples of cross carpet pages can be found in the collection of the Bibliotheque National in Paris (Syr. 30, fol. 62; Syr. 40, fol. 10v; Syr. 41, fol. 10v; Syr. 70, fol. 1) among many others. ${ }^{5}$ These four examples are also mounted on steps; manuscripts 40 and 41 contain crosses at the ends of the cross bars like our two cross-types found on the batrashil; the cross in manuscript 70 has two horizontal bars, like the triumphal cross on the stole, amid its interlacing forms; all of these crosses rely heavily on abstract geometric shapes, often creating crosses within crosses, which is also similar to the designs represented on the stole.

The cross carpet page, while known in Early Medieval manuscripts of the West, is unusual in other east Christian manuscript tradi-tions. Furthermore, there is little stylistic connection between the Western examples, made between the seventh and ninth centuries, and our stole. The prevalence and variety of crucifixes in Syriac manuscripts from the twelfth century and later make these a likely source for the cross imagery of the batrashil.

The Pentecost takes a prominent position in the top register on the front of the garment - an appropriate scene for a bishop's stole for bishops continue the Pentecostal mission of the apostles. (fig. 4) The twelve apostles are stacked in three rows of four beneath a half-disk that shoots rays, representing the tongues of fire that empowered the apostles to proselytize in other languages. On either side of the scene are two small crosses. The apostles are indistinguishable from each other, save for the bottom row where each wears a different colored cross on his chest; their facial features, hair, lack of halo, gesture with the left hand and clothing is undifferentiated.

An early thirteenth-century Syriac lectionary, today housed in the Convent of St. Mark in Jerusalem, includes a similar semicircular shape that emits rays to each apostle below. (ms. Jerusalem,

${ }^{4} \mathrm{~J}$. Leroy, Les manuscrits syriaques à peintures conservés dans les bibliothèques d'Europe et d'Orient, (Paris: P. Geuthner, 1964), 120.

${ }^{5}$ Leroy, manuscrits syriaques, 4. 
Convent of St. Mark, Syr. 28, fol. 157) ${ }^{6}$ In the center, the disk displays an enthroned dove, rather than the cross on the disk of the stole, but the iconography is nonetheless similar. In the lectionary depiction, the rays are comprised of simple lines; the disk hangs from the top center of the image like a sun in a child's drawing. Each apostle holds out his hand in a similar gesture to those on the stole, but the apostles in the St. Mark's Lectionary, however, are rendered in tiny portrait likeness, with individualized hair, coloring, and age, distinguishing it from our example.

A Syriac manuscript in the British Library illustrating the same subject treats the apostles similarly to the batrashil, placing them in a tight row with nearly identical faces and expressions, although their hand gestures are varied. (ms. London, British Library, Add. 7169, fol. $13 \mathrm{v})^{7}$ Here the apostles are touched by the same simple line, representing the Holy Spirit bestowing the gift of speaking in tongues, which descends from a semi-circular arch. This arch, however, springs over them as a rainbow rather than a convex sun shape. Their faces are depicted in heavy, dark contours that connect the nose to the brow line while the eyes stare forward beneath the thick brow. This is reminiscent of all of the faces represented on the Metropolitan's stole, including the apostles. Finally, in British Library Add. 7169, the apostles are depicted without haloes, as in our stole. Throughout the manuscript, as with the batrashil, only those figures deemed most important in each scene, often only Christ, wears a halo.

The Ascension in British Library Add. 7169 (fol. 13v) also serves as a good parallel for the batrashil. Here Christ is elevated by five angels, whose wings are distinct for their striping (representing feathers). Below, the twelve apostles stand in awe over the spectacle before them, many with their hands reaching upward while others clutch their faces, aghast. On the batrashil, Christ almost appears to stand on the ground, perhaps because of the cramped space allowed by each embroidery panel. (fig. 6) However, the cocked heads of the apostles, only two are represented here, illustrate that he is ascending above them. The abrupt upward gaze is mirrored by two of the apostles just left of center in Add. 7169. The faces of the apostles in both images again are formed by

6 W.H.P. Hatch, Greek and Syriac Miniatures in Jerusalem, (Cambridge: The Medieval Academy of America, 1931), plate LXX.

${ }^{7}$ Leroy, manuscrits syriaques, 123. 
the simple line connecting the nose and brow. While only two angels are represented in the stole, their striped wings, which jut out of the upper shoulder region, parallel those in the manuscript. Notably, in the stole, Christ is not in a mandorla as he is in Add. 7169 and most illuminations of the scene, but only wears a halo. The artist may have omitted the mandorla due to the limited space.

Absent from both Ascension scenes is the Mother of God. In Syriac manuscripts, as well as Byzantine ones, the Mother of God typically stands in the center of the scene. The St. Mark's Lectionary, discussed earlier, and the well-known Rabbula Gospels both include her in the center of the scene. This suggests a particularly close iconographic parallel between the London manuscript and the batrashil.

The Anastasis scene of the batrashil is unique among the representations of this scene in Syriac manuscripts. (fig. 6) Christ stands beside his tomb, holding a cross in his right hand, with his left hand extended toward Adam, who reaches for Christ. Next to Adam is another figure, possibly Eve, who is often represented in this scene as she is in the thirteenth-century fresco in Mar Musa alHabashi. ${ }^{8}$ However, the figure wears a crown, not the veil in which Eve is typically portrayed. The crowned David and Solomon are also typical witnesses to the scene, and the crowned figure may be either king, but more likely is the younger King David as he is beardless. ${ }^{9}$ The standard iconography pairs David and Solomon. David is shown alone in Psalters, in his guise as the inspired poet, while Solomon, when seen alone, is always shown as king. The earliest representations of David as King are found in the Early Byzantine Sinope Gospels and Rossano Gospels. ${ }^{10}$ However, there are no precedents for an Anastasis scene without Eve and with only one of the kings.

The two angels fluttering around Christ in the Anastasis are also unique to this batrashil. The unusual iconographical choices could be attributed to the small space available to the embroiderer;

${ }^{8}$ E.C. Dodd, The Frescoes of Mar Musa al-Habashi: A Study of Medieval Painting in Syria, (Toronto: Pontifical Institute of Medieval Studies, 2001).

9 See several examples of the pair in A. Kartsonis, Anastasis: The Making of an Image,(Princeton: Princeton University Press, 1986), especially plates $80,81,83,85$, and 87 .

${ }^{10}$ Kartsonis. Anastasis, 186-7. 
however, the addition of the angels makes space an unlikely issue. Therefore we may be seeing a later development of the iconography of the scene or an instance where the artist has conflated several models.

In the Crucifixion scene, Christ is flanked by two haloed figures, probably St. John and the Mother of God, creating a Deesis. (fig. 3) Two small figures stand at Christ's feet, the Roman soldiers who torment him with a vinegar-soaked sponge on his left and a spear on his right. On either side of Christ's head are two discs, likely representing the sun and moon, which signify the eclipse that occurred at his crucifixion.

While the typical late medieval crucifixion has a Deesis, the manuscript that stylistically most closely relates to the batrashil, British Library Add. 7169, does not represent Mary or John; instead the two thieves are shown beside Christ.11 (ms. London, British Library, Add. 7169, folio 11v) As if to illustrate Christ's divinity, his eyes are closed in a peaceful death while the thieves' eyes remain open. Angels are also included in British Library Add. 7169. However, the soldiers who rush in with their instruments of torture cock their heads abruptly upward, just as the soldier to Christ's left does on the batrashil. The style of the figures, particularly in the faces is also similar.

Representing the Crucifixion as a Deesis as seen in the batrashil is, however, typical in Syriac and other manuscripts. For example, the St. Mark's Lectionary uses the Deesis in its Crucifixion as well. ${ }^{12}$ (fol. 129) The St. Mark's Lectionary also depicts the sun and moon on either side of Christ's head as discs inscribed with spokes radiating out from a central point, comparable to those in the batrashil.

The Entry into Jerusalem uses the standard iconographic convention except for the direction of Christ's movement, here right to left, rather than the typical left to right. (fig. 3) Christ heads toward the city gates, not pictured, astride a donkey. He maneuvers through a crowd who throw branches down before him. Some onlookers climb trees for a better view, represented here by the figure on the far right who stands atop a branch, while others prostrate themselves before Christ, shown here by the figure in the

${ }^{11}$ Leroy, manuscrits syriaques, 122.

${ }^{12}$ Hatch, Miniatures in Jerusalem, 123. 
lower left. Several figures are shown with haloes, but the three figures nearest Christ's feet are not. Two Syriac thirteenth-century manuscripts, British Library Add. 7170, folio 115r, and Vatican, Syriac 559, folio 105r, also reveal a mixture of haloed and unhaloed figures. ${ }^{13}$ Christ enters from the right as he does in the batrashil. The manuscripts demonstrate significant Islamic, specifically Mongol, influence: the architecture of the city gates employs Islamic domed forms and geometric detailing, several figures wear turbans and other elements of Muslim dress, and the ornate floral patterns at the upper borders of each illumination resemble Islamic ornament. Save for the important iconographical similarities, stylistically Add. 7170 and Vat. Syr. 559 are more at home among thirteenth-century Islamic manuscripts, such as the many versions of the Maqamat made around this time. ${ }^{14}$

The Presentation in the Temple, the next scene on the front of the stole, is out of step with the chronology of Christ's life. (fig. 1) The Baptism has been inserted between the Nativity and the Presentation, where it should be placed after the Presentation. Limited space compelled the embroiderer to trim the Presentation scene down to its essential elements. As is typical, Mary presents Christ to the priest who stands beside a ciborium altar space; there was no room for Joseph and the prophetess Anna, who usually accompany Christ and his mother to the temple. The priest is brightly colored, and stands out from other figures on the batrashil that are simply outlined in yellow and black and partially colored with beige. The priest's vestments however are brightly colored in red, yellow and light blue rectangles; his halo is light blue with a red cross. Perhaps these vestments represent sixteenthcentury Syriac Orthodox priestly garments. As with the Entry scene, the story is read from right to left, again, perhaps indicative of the culture in which it was made.

The Baptism on the batrashil also diverges from typical representations of the scene. (fig. 7) John the Baptist stands over Christ, reaching his hand up to baptize Christ as the dove of the Holy Spirit hovers above. Christ stands in the River Jordan, as indicated by the two fish, positioned oddly to John's left, rather than beneath Christ's feet. Both men are darkly bearded, an

${ }^{13}$ Leroy, manuscrits syriaques, 86.

14 See O. Grabar, Illustrations of the Maqamat, (Chicago: University of Chicago Press, 1984). 
interesting innovation as Christ has a light-colored beard or no beard throughout the rest of the batrashil. Most unusual is the fact that Christ stands fully dressed in a modest garment decorated with flecks of orange and yellow on a dark blue background. Christ is typically shown bare or in a loincloth in scenes of baptism. In the most conservative representations, the water covers Christ's loins as in the Armenian Ejmiatsin Gospels. ${ }^{15}$ (ms. Erevan, Matenadaran 2734, folio $229 \mathrm{v}$ ) The author is unaware of any precedent for the fully clothed Christ. It seems unlikely that this represents a later development in the iconography of the Baptism, as representations of Christ get less rather than more conservative. Rather, I posit that this Christ is modeled on some other unknown scene, because of his clothing and dark beard, and the embroiderer has inserted him into the Baptism.

The Nativity employs standard iconography. (fig. 7) The Virgin and Child rest, somewhat awkwardly, in the center of the scene. An angel, whose wingspan envelops over half of the space, attends them. One of the Magi, who stands in for all three, steps forward from the left, wearing grand, brightly colored robes in yellow, light blue, green and black, with tassels of some kind streaming from his head. A minor figure is squeezed in at the right, perhaps a shepherd, and wears no halo.

The last of the narrative scenes on the front of the stole in the bottom register is the Annunciation. (fig. 7) The Angel Gabriel, lands with wings of yellow, green and white still beating, and extends his hands to the Mother of God, who holds up her hands in a mixture of surprise and fear. She is dressed colorfully in a garment striped in red, white and yellow with a blue mantle. Her halo is decorated at the corners with green and red accents. The inscription over the Annunciation scene reads "Annunciation to the Mother of God," leaving no doubt that this vestment belongs to the Syriac Orthodox church.

The back of the stole contains standing portraits of the each of the four evangelists. (figs. 2 and 5) Few examples of such portrait types exist in manuscripts for comparison, where the author portrait format, showing the evangelist seated and writing, is standard. The Syriac Rabbula Gospels (ms. Florence, Medicaean-

${ }^{15}$ John Lowden, "The Beginnings of Biblical Illustration," in Imaging the Early Medieval Bible, ed. John Williams, (University Park: The Pennsylvania State University Press, 1999), figure 18. 
Laurentian Library, Syr. Plut I, 56), which depict Luke and Mark standing, clutching their gospels, beside their canon table on folio 10a, form a rare exception. ${ }^{16}$ The more naturalistic style of the Rabbula illumination and the dress of the evangelists within - they wear the Roman striped tunic and pallium - distinguish it from the representations of Luke and Mark on the stole. The stole's portraits, instead, depict the evangelists frontally, each wearing a large, tent-like garment, heavily patterned with checks, stripes, and zig-zags. Each wears a distinct halo, decorated with multiple crosses, and each holds a book, displaying it for the viewer. Frontal portraits of standing holy figures are known in fresco painting, such as the thirteenth-century examples in Mar Musa alHabashi. As the bishop named on the stole was affiliated with this monastery, these serve as a good comparison. Stylistically, the clothing of the figures is more naturalistic in the frescoes, which do not employ the naïve patterns used to decorate vestments on the stole. Furthermore, the faces at Mar Musa al-Habashi are not contoured in a single outline with an attached brow and nose as they are on the stole and in related manuscripts. Nevertheless, the numerous portraits in Mar Musa al-Habashi could have served as inspiration for this unusual iconographic element on the stole.

In addition to the iconographical affinities with Syriac manuscripts generally, there are strong stylistic similarities with British Library Add. 7169 in particular. The faces of figures in both works are drawn with a connected nose and brow line and large staring eyes. Figures are similarly stacked up to represent a deep crowd in scenes such as the Entry into Jerusalem. The angels in Add. 7169, with their often oversized, striped wings resemble those in the stole. Several figures in both objects cock their heads looking upward to Christ in the Crucifixion and the Ascension, for example. Finally, the crosses mirror those found in several manuscripts, particularly mss. Paris, Bibliothèque National, Syr. 30 and 40.

16 Carlo Cecchelli, Guiseppe Furlani, and Mario Salmi eds., The Rabbula Gospels: Facsim. ed. of the miniatures of the Syriac ms. Plut. I, 56 in the Medicaean-Laurentian Library, (Olton: Urs Graf, 1959). Folio 10a. 


\section{Post-Medieval Byzantine Vestments}

While there are no other Syriac Orthodox vestments with which to compare the batrashil, it is generally agreed that Syriac Orthodox vestments descend from Byzantine ones at least in overall form. Byzantine vestments provide for fruitful comparison, for their iconographic programs have been studied extensively, unlike the vestments of other East Christian churches which, for the most part, have only been catalogued according to the types and uses of different garments. ${ }^{17}$ The scenes decorating this particular batrashil - nine of the twelve festal scenes and the four evangelists with a triumphal cross-are somewhat unusual when compared with Byzantine counterparts. The Great Deesis, Christ flanked by the Virgin and St. John and other saints, adorn the majority of Byzantine epitrachelia, the Byzantine equivalent to the batrashil, while the festal cycle is a secondary choice that develops later. ${ }^{18}$ The embroiderer of the Metropolitan's batrasbil omitted three scenes from the usual twelve feasts-the Raising of Lazarus, the Transfiguration, and the Dormition of the Virgin-further distinguishing its iconography from Byzantine examples. The Evangelists are on occasion represented on a Byzantine bishop's stole but there they are accompanied by the Apostles and the Virgin, not shown in isolation as they are on the Metropolitan's example. The style of embroidered scenes on the stole is decidedly not Byzantine or post-Byzantine either. Vestments from the Greek Orthodox Church, by the date the stole was made, reflect Italian Renaissance art, with its concern for naturalism and threedimensionality.

Latin Catholic stoles-maniples and pallia-contain Christological scenes arranged in registers, ${ }^{19}$ raising the issue of

17 Warren Woodfin addresses the iconography of vestments in W. Woodfin, Late Byzantine Liturgical Vestments and the Iconography of Sacerdotal Power. (Ph.D. dissertation, U. of Illinois Urbana-Champagne, 2002) as does Tano Papas in Papas, Studien zur Geschichte der Messgewänder im byzantinischen Ritus, (Munich: Institut für Byzantinistik und Neugriechische Philologie der Universität, 1965). For studies of Byzantine and other East Christian vestments see: Joseph Braun, Die Liturgische Gewandung im Occident und Orient, (St. Louis: Herder, 1907) and Karel C. Innemée, Ecclesiastical Dress in the Medieval Near East, (Leiden: E.J. Brill, 1992).

18 Woodfin, Late Byzantine Liturgical Vestments, 73-80.

${ }^{19}$ See for example Braun, Liturgische Gewandung, figs 260 and 279. 
Crusader influence. The road from Damascus to Homs, where, according to its inscription, the stole was made, was a major Crusader route. The style of the embroidery and use of the stole, however, shows no similarity to Catholic vestments. Moreover, by the sixteenth century only the Syrian Maronite Church, which joined the Catholic Church during the Crusader period, exhibited any vestigial influence of the Latin Church. Not surprisingly the stole follows the iconographical traditions of other forms of Syriac Orthodox art, rather than Byzantine or Western ecclesiastical garments, even though the origins of the vestment itself are Byzantine.

\section{Connections to Coptic AND NUbIAN ART}

While the embroiderer clearly used older medieval Syrian models, as can be seen in the stylistically similar manuscripts, the object can also be linked to the wider world of Syria's neighboring Coptic and medieval Nubian churches, which offer numerous stylistic comparisons. The numerous connections between the Copts and Christian Syrians - in their hagiographic literature, liturgical practices, official contacts, and artistic exchange-has been explored in depth by J.M. Fiey. ${ }^{20}$ Fiey also observes links with the Nubian Monophysite church, especially with regard to the production of manuscripts. ${ }^{21}$ In the late Middle Ages, when Islam subsumed the Nubian Kingdoms, the remaining church leadership in Nubia was united with the Coptic Church. ${ }^{22}$

The local tradition surrounding the founding of the Mar Musa al-Habashi monastery holds that it was built in the sixth century on the gravesite of a fourth-century Ethiopian monk, Moses the Ethiopian. ${ }^{23}$ Hubert Kaufhold has demonstrated that a Syrian monk, also named Moses, likely founded the monastery rather than Moses the Ethiop-ian. ${ }^{24}$ Nevertheless, the tradition illustrates the

20 J.M. Fiey, "Coptes et Syriaques: contacts et échanges" (Studia Orientalia Christiana Collectanea 15 [1972/3]), 295-365.

${ }^{21}$ Fiey, Coptes et Syriaques, 311-15.

22 W.Y. Adams, "The United Kingdom of Makouria and Nobadia: A Medieval Nubian Anomaly" in Egypt and Africa: Nubia from Prehistory to Islam, ed. W. V. Davies (London, 1991), 258.

${ }^{23}$ Dodd, Frescoes of Mar Musa al-Habashi, 9.

${ }^{24}$ Hubert Kaufhold, "Notizien über das Moseskloster bei Nabk und das Juliankloster bei Qaryatain” (OrChr, 79 [1995]), 54-9. 
close connections between these three cultures-Nubian, Copt and Syrian. ${ }^{25}$ Syrian and Nubian monks, through the intermediary of Egyptian monasteries, linked Nubian and Syrian liturgical practice, literature and artistic production. Indeed, several specific sites of Coptic painting, discussed below, are known to have fostered exchange. Those sites, moreover, exhibit important stylistic similarities to the Metropolitan's batrashil. Finally, visual connections between Christian Nubian art, which was no longer produced in the sixteenth century, and the Syrian stole can be demonstrated; though the Nubian links exist through the filter of Egypt.

Paintings found at the Monastery of Deir al-Surian (Syrian Monastery) and the Monastery of St. Antony, both in Egypt, offer the most compelling comparisons. ${ }^{26}$ Of the most recent frescoes, dating to the thirteenth century, all exhibit similar facial features to figures on the stole, with their staring, round eyes. While the figures on the stole are cruder than those found in the frescoes of Coptic monasteries, the connected brow-line and nose and simplistic beards are a mark of many thirteenth-century Coptic paintings. Syrians founded Deir al-Surian, and both Deir al-Surian and St. Antony's Monastery, housed Syrian as well as Egyptian monks. ${ }^{27}$ Deir al-Surian was influential enough to produce a patriarch of the

25 The veneration of Moses the Ethiopian continues even today at Deir el-Baramus in Egypt.

${ }^{26}$ For images of the thirteenth-century paintings see G. Gabra, Coptic Monasteries: Egypt's Monastic Art and Architecture, (Cairo: American University in Cairo Press, 2002) and E. Bolman ed. Monastic Visions, (New Haven: Yale University Press, 2002). For dating and stratigraphy of the paintings at Deir al-Surian see: K.C. Innemée, "Recent Discoveries of Wall-Paintings in Deir Al-Surian" (Hugoye: Journal of Syriac Studies 1:2 [uly 1998]) ; K.C. Innemée, "Deir al-Surian (Egypt): conservation work of Autumn 2000" in (Hugoye: Journal of Syriac Studies 4:2 [July 2001]) and Karel C. Innemée, "A Newly Discovered Mural Painting in Deir al-Surian," (Eastern Christian Art in its Late Antique and Islamic Contexts 1 [2004]), 61-66. Innemée published images of the earlier layers in these studies which would have been covered at the time of the batrashil was made.

27 Gawdat Gabra argues that a Syrian population waxed and waned throughout its history but had a resurgence in the middle of the sixteenth century in G. Gabra, Coptic Monasteries, 49 and Elizabeth Bolman gives evidence of Syrians at the Monastery of St. Antony in E. Bolman, Monastic Visions, 175. 
Coptic Church in the middle of the sixteenth century, Gabriel VII; his attempt to re-populate the abandoned monasteries of Egypt, which included a reconstruction of the Monastery of St. Antony, formed his legacy as Patriarch. ${ }^{28}$ Along with these multicultural monastic communities, artist-monks and illuminated manuscripts must have traveled between the Egyptian monastic center of Wadi al-Natrun and the Syriac Orthodox monasteries.

Coptic manuscripts, too, show visual parallels with the Metropolitan's batrashil. In addition to the distinct facial structure of the connected nose and brow line, many figures wear vestments with dense geometric patterns like those found on the edges of the garments of the Evangelists on the back of the batrashil. (Fig. 5) For example, St. Stephen pictured in the ms. New York, PierpontMorgan Library 577, folio 1 verso wears two stoles layered over his vestments, all with zigzags, stripes, chevrons and several types of cross shapes busily ornamenting each garment. ${ }^{29}$

Nubian art also exhibits the facial features found on the batrashil. For example the straightforward gazes of the rigidly posed abbots on folio 8 verso and the expressionless faces of Herod and his soldiers on folio 11 verso in the fourteenth-century Four Gospels of Krestos Tasfana are analogous to the facial types seen on the stole. The Krestos Tasfana Gospels were made in the famous scriptorium Dabra Hayq Estifanos, in Amhara, well known throughout the sixteenth century. ${ }^{30}$ Further elements for comparison can be found in other Nubian objects. The peculiarly cocked heads of the apostles in the Ascension of Christ (Fig. 6) and of the Roman soldier in the Crucifixion (Fig. 3) on the batrashil are seen on the twelve apostles surrounding Christ on an early fifteenth-century Nubian processional cross. ${ }^{31}$ Additionally, much like the figures on the stole, the shoulders of the figures on the cross, notably the archangel on the shaft of the cross, slope into shapeless garments with incised cross-hatching and stripes as the only decoration. The archangel's large formless body parallels the Evangelists' on the stole; the striped wings of figures on the

${ }^{28}$ Gabra, Coptic Monasteries, 49 and Bolman, Monastic Visions, 174.

${ }^{29}$ Innemée, Ecclesiastical Dress, plate 44, figure 1.

30 Published in M. Heldman et al, African Zion: The Sacred Art of Ethiopia, (New Haven: Yale University Press, 1993), cat. no. 65. On the scriptorium see page 141.

${ }^{31}$ Heldman, African Zion, cat. no. 72. 
Nubian cross too mirror the angels' wings in scenes on the front of the batrashil. Syrian and Nubian exchange is more difficult to demonstrate as it occurred through the filter of Egyptian monasteries and the Coptic Church, after the Nubian church had died out. Still, the rendering of figures in the batrashil and the Nubian pieces discussed here makes these contacts clear.

While no Coptic or Nubian liturgical vestments of this period survive with which to compare with the Syrian stole, other art forms compare stylistically. This is not surprising as it is widely thought that artists used manuscripts as model books for monumental painting and other media. The frequent exchange between the cultures of the West Syrian Church and the Coptic and Nubian churches is apparent in these stylistic comparisons. The Coptic and Nubian objects also relate to the Syriac manuscripts discussed earlier, suggesting, perhaps, that the maker of the stole used late medieval pictorial models similar in style across the Syrian, Coptic and Nubian churches.

\section{LITURGICAL USE OF THE BATRASHIL}

Syriac Orthodox liturgical practice, and likely the vestments used, also shares much in common with the Coptic and Nubian churches. The term batrasbil is an Arabic word used in the Coptic and West Syrian churches to describe the stole of a bishop. ${ }^{32}$ It is worn with another stole, the hamniko, which is thinner, shorter and worn like a necklace. ${ }^{33}$ Both of these stoles are derived from their Byzantine counterparts, the orarion (priestly stole) and epitrachelion (bishop's stole). The Byzantine epitrachelion encircles the neck like a scarf, hanging down in two pieces on either side of the chest. In the late medieval period, these two ends were joined. However, our batrashil, which is worn like a sandwich board over the front and back of the torso, remains distinct from the Byzantine version even with this late refinement. Medieval pictorial evidence cannot be used to confirm that the Syrian batrasbil fell down the shoulder blades or whether it continued to follow the Byzantine model, covering only the front of the body, as the backs of figures are not shown. Nevertheless, today priests and bishops in the Syriac Orthodox church wear a vestment like the Metropolitan's batrashil,

32 Innemée, Ecclesiastical Dress, 45.

33 Innemée, Ecclesiastical Dress, 72. 
hanging down in front and back, leading one to imagine that the change in form happened late in or after the medieval period. Very possibly the Metropolitan's piece represents the earliest of the modern contour of batrashil, which folds over the front and back of the torso.

Priests and bishops wore the stole for all major liturgical events. Descriptions of ordination and promotion ceremonies by medieval writers, however, in which the batrashil plays an important role, offer the best understanding of its symbolic meaning. Priests were vested with the stole during ordination and the bishops wore it for consecration. Ms. Paris, Bibliothèque National, Syr. 112 written in $1239 \mathrm{CE}$ tells us that priests wore the stole around the neck at the conclusion of the ceremony. ${ }^{34}$ Ms. Vatican, Syr. 51, dated to $1171 / 2 \mathrm{CE}$, notes that the bishop wears the stole as the patriarch hoods him for promotion. ${ }^{35}$

This use parallels Coptic descriptions of the same ceremonies. ${ }^{36}$ Arabic 236 in the Coptic Patriarchal Theological Library in Cairo, a book of ca. 1200 CE copied in ca. 1719 CE, observes that the priest was led around the church by the stole, as if it were a leash, to introduce him at the beginning of the ordination ceremony. ${ }^{37}$ The fourteenth-century Book of the Precious Pearl of Ecclesiastical Knowledge describes a similar ceremony in the Coptic Church for the promotion of a bishop; here the new bishop is pulled around the church by the batrashil by three other bishops who present him to the worshippers present. 38

The Byzantine Patriarch Germanos describes the epitrachelion as the metaphorical rope around Jesus' neck used to lead him to his crucifixion. ${ }^{39} \mathrm{~A}$ fourteenth-century interpretation by Nicholas Kabasilas sees the stole as a visual metaphor for the priesthood, where the priest bears the 'yoke of Christ." Coptic liturgical practice favored Germanos' understanding of the stole, then, and incorporated it into church practice. Apparently, the Syriac

${ }^{34}$ Innemée, Ecclesiastical Dress, 67.

35 B. de Smet, "Le rituel du sacre des évêques et des patriarches dan l'église Syrienne d'Antioche" (OrSyr, 8 [1963]), 172.

36 Innemée, Ecclesiastical Dress, 30-39.

${ }^{37}$ Innemée, Ecclesiastical Dress, 31.

${ }^{38}$ Innemée, Ecclesiastical Dress, 33-4.

39 Bernardakis, "Les ornements liturgiques chez les Grecs" (Échos d'Orient, 5 [1901-2]), 130. 
Orthodox Church followed suit, as seen on folio 69r of ms. Paris, Bibliothèque National, Syr. 112. Three bishops stand behind a fourth one who is being ordained, implying that they have just finished leading him through the church and are now witnessing the completion of his promotion by the patriarch, mirroring the Coptic rite. 40

\section{THE INSCRIPTIONS}

The inscriptions, in Syriac and Arabic, further fix the object within its context, and speak directly to the circumstances under which the object was made. The embroiderer inscribed the stole in Arabic around the neck, naming the owner, and on the edges, stitched a eulogy. Each scene on the front and the Evangelists portraits on the back are identified in Syriac. An additional inscription identifying the patron is embroidered in Syriac above each Evangelist. The use of these two languages in Syria is not unusual at this time, when the vernacular and official language of Syria was Arabic and Syriac was used only in the Christian church.

The Syriac inscription, is cursorily translated here for discussion.

Inscribed in Syriac (above each scene on the front, top to bottom): Pentecost; Ascension of our Lord into heaven; The saving resurrection (or Resurrection of the Savior); (bottom of scene) Adam; The tomb [of Christ]; Entry of our Lord into Jerusalem; Entry of our Lord into the Temple; Baptism of the Lord from John; (top left of Baptism scene): Heaven; Birth of our Lord in the flesh; (bottom center of Nativity scene): Manger; Annunciation to the mother of God (above each Evangelist on the back, top to bottom): May Athanasius be pardoned; in name, a bishop; who is Abraham Yaghmur; son of Isa from the village of Nebek. (Evangelists named, top to bottom): Matthew, the Apostle and the Evangelist, Mark, Luke, John the Evangelist.

Bishop Athanasius, named in the inscription, is securely identified from several colophons dating to the mid-sixteenth century. ${ }^{41}$ He was Bishop of Homs, near Nebek, and Hardinn in the

${ }^{40}$ Leroy, manuscrits syriaque, 333 and plate 112.

${ }^{41}$ His name is found in several Syriac manuscripts from the period, for example: ms. Oxford 125, Lectionary from the Church of St. Theodore in Șadad, Syria, ms. Paris, Bibliothèque National, Syr. 145, ms. 
middle of the sixteenth century. In four of these colophons he is named by the name of his bishopric as well as his true name,

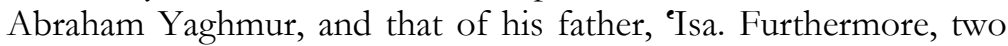
manuscripts mention his home village of Nebek, making the identification of this stole's owner with the Bishop Athanasius Abraham Yaghmur in the colophons unmistakable. Bishop Athanasius was a scribe and, according to one colophon, he worked in the monasteries of Mar Julian al-Qaryatein and Mar Musa al-Habashi. ${ }^{42}$

The monastery of Mar Musa al-Habashi, located near Nebek, and its sister monastery of Mar Julian al-Qaryatein, in the desert east of Damascus, have illustrious histories extending back to the sixth century CE.43 Mar Musa al-Habashi was a well-known scriptorium in the medieval period, which had a particularly productive period in the fifteenth century. ${ }^{44}$ Inventories of the period list several manuscripts that were made there. The monastery flourished in other arts as well, as its fresco program attests. It was restored in 1556, suggesting that during Bishop Athanasius' association with the monastery, the scriptorium and monastery were thriving. ${ }^{45}$

The historical inscription of the Arabic, written in Nashki script, names both the bishop and the maker, and contains a eulogy. Inscribed in Arabic (around the edge of the neckline): The work is made by the clergyman Abraham, by name bishop Yaghmur, and of the teacher Shaqra daughter of Daniel (?) in the city of Hama in the year one thousand 648 in the calendar of the Greeks. (edges of front of garment): a eulogy beginning "Glory to God the Highest..." (back of garment, left edge): ...priest (?)...for the son (?)...And the hope [for] Peace on earth.... (right edge) I

Paris, Bibliothèque National, Syr. 160, Lectionary from the Church of Mar Sarkis, Șadad, Syria, ms. Paris, Bibliothèque National, Syr. 108, and ms. Jerusalem, Convent of St. Mark, Syr. 249. Thanks to Hubert Kaufhold for these colophons and the identification of the bishop.

${ }^{42}$ Lectionary of Church of St. Theodore, Sadad, Syria in F. Dulabani, Catalogue of Syriac Manuscripts in Syrian Churches and Monasteries, (Halab: 1994), 332-3.

${ }^{43}$ Kaufhold, Notizien, 48-119.

${ }^{44}$ Dodd, Frescoes of Mar Musa al-Habashi, 11.

${ }^{45}$ Dodd, Frescoes of Mar Musa al-Habashi, 12. 
fear from whom my life...the Lord I fear! (See Appendix for a complete discussion of the Arabic.)

The historical inscription confirms the name of the Bishop Abraham Yaghmur but gives a date of 1648 in the Seleucid calendar (=1336/7 CE). ${ }^{46}$ The Arabic and Syriac are of one hand and embroidered into a single piece of silk, meaning that both inscriptions should bear the same date. ${ }^{47}$ It is possible that the embroiderer copied an older fourteenth-century object. That would explain why the style of the figures does not reflect sixteenthcentury ecclesiastical embroideries, which attempt to model figures with shading and create some sense of three-dimensional space with architectural and landscape elements, nor Mamluk or Ottoman tastes, the ruling dynasties of sixteenth-century Syria. ${ }^{48}$ However, the Arabic inscription naming the same Bishop Athanasius Abraham Yaghmur as the Syriac text, makes it very unlikely that it was copied from an earlier object, for it would rely on the existence of a fourteenth-century bishop of the same name. While Athanasius Abraham is not an uncommon name, the added details of his father's name, village, and his second or family name of Yaghmur distinguish him from others. The author could locate only one Athanasius Abraham in the fourteenth century, and he was a Maphrian, ${ }^{49}$ an important title likely to be indicated on the stole. A Bishop Abraham from the "convent of Natpha [i.e. Nebek]," as al-Habashi was sometimes known, is mentioned in

46 The Seleucid calendar was commonly used in Syriac Orthodox inscriptions by the twelfth century and was used up until the eighteenth century at Mar Musa al-Habashi. Dodd, Frescoes of Mar Musa al-Habashi, 17.

${ }^{47}$ In addition to my own examination of the object where this is clearly observed, Nobuko Kajitani, Metropolitan Museum of Art Textile Conservator, who worked on the object in the 1970s and again in 2002-3 confirms this.

48 See for example the sixteenth-century Epitrachelion from the Stavronikita Monastery published, along with many other examples of liturgical embroideries from this period, in: Athanasios A. Karakatsanis ed., Treasures of Mount Athos, (Thessalonike: Ministry of Culture, 1997), cat. no. 11.7. Large, brightly colored floral patterns were typical of Islamic embroidery at this time, see for example: Jennifer Harris ed., Textiles 5,000 Years, (New York: Harry N. Abrams, 1993), fig. 96.

49 J.M. Fiey, Pour un Oriens Christianus Novus. (Stuttgart: In Kommission bei F. Steiner, 1993), 34. 
1319 CE. ${ }^{50}$ However, in that case Abraham was probably the name taken upon ordination as bishop, as that is the only name given. Moreover, the absence of the name Athanasius seems to point to a different person. Furthermore, neither of these fourteenth-century bishops have the name Yaghmur or a father named Isa, so far as we know. This leaves the possibility that the numbers were written backwards and should be read as "one thousand 846" as opposed to 648. Typically, artists, many of whom were illiterate, simply copied letters and numbers from their patron's instructions when inscribing works. When read as 1846 in the year of the Greeks, the object can be dated to $1534 / 5$, certainly within the lifetime of our Bishop Athanasius Abraham Yaghmur.

The Arabic, I argue, lends additional details about the embroiderer. She was a woman who likely spoke Arabic herself, as Syriac was only used in the liturgy by this date. ${ }^{51}$ We cannot be certain of her religion, Muslim or Christian, as members of both religions spoke Arabic. In a study of a thirteenth-century flabellum made for Christians in Islamic Northern Mesopotamia, Bas Snelders and Mat Immerzeel have suggested that a Syriac inscription probably points to a Christian artist, at least for the engraving. ${ }^{52}$ Inscriptions can be copied without knowledge of the language, however, and even a Christian artist would not necessarily be literate in a language used solely for the liturgy and some literature; we simply cannot guess the embroiderer's religion.

The stole was "made by" both the bishop and a "teacher" named Shaqra, daughter of a certain Daniel. ("Daniel" is not completely legible but is likely). The bishop did not literally make the stole, however; more likely he commissioned it with specific instructions as to its iconography and inscription. The names of patrons are commonly inscribed as "makers" of objects in medieval Islam and Byzantium. Shaqra, then was the only actual maker of the stole. The title of "teacher" likely refers to her position as a master embroiderer, possibly in charge of apprentices. A guild

50 W. Wright, Catalogue of Syriac Manuscripts in the British Museum (London: British Museum, 1870-72), 469.

${ }^{51}$ British Library, Christian Orient, 26.

52 Bas Snelders and Mat Immerzeel, "The Thirteenth-Century Flabellum from Deir al-Surian in the Musée Royal de Mariemont (Morlanwelz, Belgium)," (Eastern Christian Art in its Late Antique and Islamic Contexts 1 [2004]), 130-1. 
system, not unlike those of the medieval West developed in Islam after the fourteenth century. Guilds were established under the Mamluks, who ruled Syria at the time the stole was made, and they reached their pinnacle under the Ottomans in the later sixteenth century. ${ }^{53}$ Damascus in particular was noted for its large silkweaving guild around $1492 \mathrm{CE}$ and again in the sixteenth century. ${ }^{54}$

Notably, Shaqra was a woman. Sources give little information about women artists; the majority of guilds had only male members, and mixed guilds would be unlikely given the separation of the sexes in the social life of Islam. Still there is evidence in the form of bans against women selling their wares at markets, the occasional work of art inscribed with a woman's name, and the sporadic mention of women artisans in literature, suggest that it was not as unusual for a woman to work as an artist as the lack of sources might suggest. 55 Weaving and working with textiles were considered acceptable professions for women and women still dominate the field today. It cannot be stated for certain that Shaqra participated in a guild, but her hierarchical title implies it.

Our embroiderer worked in the city of Hama, according to the inscription, which is just north of Homs along a major trade route. While this is far north of Damascus where sources describe the primary activities of the Syrian textile industry (and the weave damask gets its name), there is a long history of textile production in other Syrian cities as well. Tyre and Beirut, for example, were known as weaving and dying centers dating back to Byzantine times; the Prophet Mohammed himself was a textile merchant prior to his revelations, following the north-south trade route that still today passes through Hama and Homs. Syria, with its busy textile trade and production, provided a ripe environment for the production of the batrashil, with its precious blue-dyed silk, embroidered with silver threads.

\section{CoNCLUSIONS}

The Metropolitan's batrashil opens a window into sixteenth-century Syria, particularly the Syriac Orthodox community. The community

53 Robert Irwin, Islamic Art in Context, (New York: Harry N. Abrams, 1997), 135.

${ }^{54}$ Irwin, Islamic Art, 156.

55 Irwin, Islamic Art, 140. 
of Mar Musa al-Habashi, where the owner of the stole presided, was active and flourishing, as evidenced not only by the restoration of frescoes there in the sixteenth century but also by the fact that the bishop had the means to travel and commission this expensive piece of embroidery. The iconographical choices borne out in the stole also reveal that while the Syriac Orthodox community must have had ties with other Eastern Orthodox communities, such as the Coptic church, some of the unusual iconographic choices demonstrate the independence, at least of this monastery. The stole finally points to the linguistic flexibility of the Arabic-speaking population of Mamluk Syria. Despite the fact that this is an ecclesiastical garment, it was inscribed with both Arabic and the Syriac used in the church.

Karel Innemée's important work on representations of ecclesiastical dress in the medieval Near East concludes that Syrian and Egyptian vestments had Byzantine roots and then evolved along similar lines, due to their close relationship, while the Armenian Church vestments exhibit important differences. ${ }^{56}$ Nubian vestments, he adds, have been influenced by the Byzantine and Coptic cultures. The batrashil in its style, iconography, and liturgical use follows the same paradigm. It evolved from the Byzantine epitrachelion but the style is most closely related to Coptic and Nubian art. The use of the stole in Syrian ordination ceremonies also parallels Coptic practice, and probably by extension Nubian use.

The inscription sets the stole in the second-quarter of the sixteenth century, at the end of Mamluk rule in Syria, and just before the Ottoman Empire expanded into the region, which explains the dual Arabic and Syriac inscription, common for Christian objects in this culture. The inscription also places the batrashil in the hands of a learned bishop who acted as scribe for several manuscripts and was affiliated with the famous scriptorium at Mar Musa al-Habashi.

The woman artist named on the batrashil adds at least a little information to the dearth of sources on women in Islam in this period. It demonstrates that women worked as skilled textile workers and held some authority, as Shaqra's title of "teacher" implies. Perhaps her title further suggests that she worked in some

${ }^{56}$ Innemée, Ecclesiastical Dress, 179-86. 
sort of guild system, but this cannot be said with any certainty. While we cannot say whether or not she was a Christian or part of the majority Muslim population, the use of both Arabic and Syriac may point to a workshop where Christians and Muslims worked together. ${ }^{57}$ The bishop who commissioned the batrashil, it should be pointed out, traveled to another city to purchase the vestment, suggesting that there were no embroiderers any closer to him or that more skillful artisans were to be found in Hama. The stole must have been expensive, as metallic threads and silk were used in addition to the bright blue dye of the silk. Blue of this color, made probably from indigo, or perhaps lapis lazuli (although the dye of this garment has not been analyzed) which were both very expensive. Indigo had to be imported from Central Asia; lapis was found locally but was considered very precious. The expense of the stole attests not only to the wealth of Bishop Athanasius, but also to the high-quality textiles produced by Shaqra or her workshop.

The sixteenth-century date of the batrasbil allows scholars of liturgical dress to form a continuum between medieval Syrian vestments and modern ones. The batrashil specifically was not added to the Syrian bishop's vestments until the thirteenth century - two centuries after its appearance in the Byzantine and Coptic Churches-although the use of some type of stole in liturgical practice dates back much farther. If the Coptic and Byzantine models were followed closely then the first batrashil only hung down the front of the body in its early evolution. Modern versions of the batrashil that fall behind and in front of the torso have been thought to date back to the early eighteenth or late seventeenth-century at most. ${ }^{58}$ The Metropolitan's stole predates these examples by nearly two centuries making this form significantly older than was previously thought.

Furthermore, the iconographical shift to Christological scenes occurred in Byzantine epitrachelia in the fourteenth century, and then only occasionally.59 Representations of this type of stole demonstrate that the festal cycle was not common in Coptic or

57 Snelders and Immerzeel demonstrate this to be the case in a metal workshop in Northern Mesopotamia. Snelders and Immerzeel, "Thirteenth-Century Flabellum," 131.

${ }^{58}$ Innemée, Ecclesiastical Dress, 46.

${ }^{59}$ Woodfin, Late Byzantine Liturgical Vestments, 78. 
Nubian stoles either. However, the embroiderer could have followed the many examples from Syriac illuminated manuscripts, perhaps found in the scriptorium where Bishop Athanasius worked, rather than having to search for another vestment. Perhaps Bishop Athanasius' instructions to the embroiderer were unusual even for his time, but given the conservative iconography of vestments generally and the archaizing style of this particular stole, this seems unlikely. This stole fills a gap in the sixteenthcentury when the feast cycle, or an abbreviated version of it, must have become more commonplace in the Syriac Orthodox vestments, if not vestments of the Eastern Orthodox churches in general.

The Metropolitan's batrashil points up the need for further research into Syrian vestments, along with Syriac Orthodox art of the post-medieval period. The stole hints at a shift in the form and iconography of Syriac Orthodox vestments since the medieval period; more examples could fill the evolutionary gaps. Finally, the inscription on the stole furthers our knowledge of Christians living in Mamluk Syria, a period that has fallen between scholars of medieval Christians in early Islam and Ottomanists.

\section{BIBLIOGRAPHY}

Adams, William Y. "The United Kingdom of Makouria and Nobadia: A Medieval Nubian Anomaly" in Egypt and Africa: Nubia from Prehistory to Islam, W. V. Davies ed., London: 1991, 257-63.

Beilouny, G. A Remarkable Collection of Ancient Works of Art, New York: Fifth Avenue Auction Rooms, 1919.

Bolman, Elizabeth ed. Monastic Visions. New Haven: 2002.

Braun, Joseph. Die Liturgische Gewandung im Occident und Orient. St. Louis: Herder, 1907.

British Library. The Christian Orient. London: 1978.

Carlo Cecchelli, Guiseppe Furlani, and Mario Salmi eds. The Rabbula Gospels: Facsim. ed. of the miniatures of the Syriac ms. Plut. I, 56 in the Medicaean-Laurentian Library. Olton: Urs Graf, 1959.

Dodd, Erica Cruikshank. The Frescoes of Mar Musa al-Habashi: A Study of Medieval Painting in Syria. Toronto: 2001.

Dulabani, F. Catalogue of Syriac Manuscripts in Syrian Churches and Monasteries. Halab: 1994.

Fiey, Jean Maurice. "Coptes et Syriaques: Contacts et Échanges." Studia Orientalia Christiana Collectanea 15 (1972/3): 295-365.

-. Pour un Oriens Christianus Novus. Stuttgart: In Kommission bei F. Steiner, 1993. 
Gabra, Gawdat. Coptic Monasteries: Egypt's Monastic Art and Architecture. Cairo: American University in Cairo Press, 2002.

Grabar, Oleg. Illustrations of the Maqamat. Chicago: University of Chicago Press, 1984.

Harris, Jennifer (ed.). Textiles 5,000 Years. New York: Harry N. Abrams, 1993.

Hatch, William Henry Paine. Greek and Syrian Miniatures in Jerusalem. Cambridge: The Medieval Academy of America, 1931.

Heldman, Marilyn et al. African Zion: The Sacred Art of Ethiopia. New Haven: Yale University Press, 1993.

Innemée, Karel C. Ecclesiastical Dress in the Medieval Near East. Leiden: E.J. Brill, 1992.

—. "Recent Discoveries of Wall-Paintings in Deir Al-Surian."Hugoye: Journal of Syriac Studies 1:2 (July 1998).

—. "Deir al-Surian (Egypt): conservation work of Autumn 2000." Hugoye: Journal of Syriac Studies 4:2 (July 2001).

-. "A Newly Discovered Mural Painting in Deir al-Surian." Eastern Christian Art in its Late Antique and Islamic Contexts 1 (2004): 61-66.

Irwin, Robert. Islamic Art in Context. New York: Harry N. Abrams, 1997.

Karakatsanis, Athanasios A. ed. Treasures of Mount Athos. Thessalonike: Ministry of Culture, 1997.

Kartsonis, Anna. Anastasis: The Making of an Image, Princeton: Princeton University Press, 1986.

Kaufhold, Hubert. "Notizien über das Moseskloster bei Nabk und das Juliankloster bei Qaryatain in Syrien" in OrChr 79 (1995), 48-119.

Leroy, J. Les manuscrits syriaques à peintures conservés dans les bibliothèques d'Europe et d'Orient. Paris: P. Geuthner, 1964.

Lowden, John. "The Beginnings of Biblical Illustration," in Imaging the Early Medieval Bible. John Williams ed. University Park: The Pennsylvania State University Press, 1999.

Papas, Tano. Studien zur Geschicte der Messgewänder im byzantinischen Ritus. Munich: Institut für Byzantinistik und Neugriechische Philologie der Universität, 1965.

de Smet, Dom B. "Le rituel du sacre des évêques et des patriarches dan l'église Syrienne d'Antioche." OrSyr 8 (1963): 165-212.

Snelders, Bas and Mat Immerzeel. "The Thirteenth-Century Flabellum from Deir al-Surian in the Musée Royal de Mariemont (Morlanwelz, Belgium)." Eastern Christian Art in its Late Antique and Islamic Contexts 1 (2004): 113-139.

Woodfin, Warren. Late Byzantine Liturgical Vestments and the Iconography of Sacerdotal Power. Ph.D. dissertation, U. of Illinois UrbanaChampagne, 2002. 
Wright, W. Catalogue of Syriac Manuscripts in the British Museum. London: British Museum, 1870-72. 


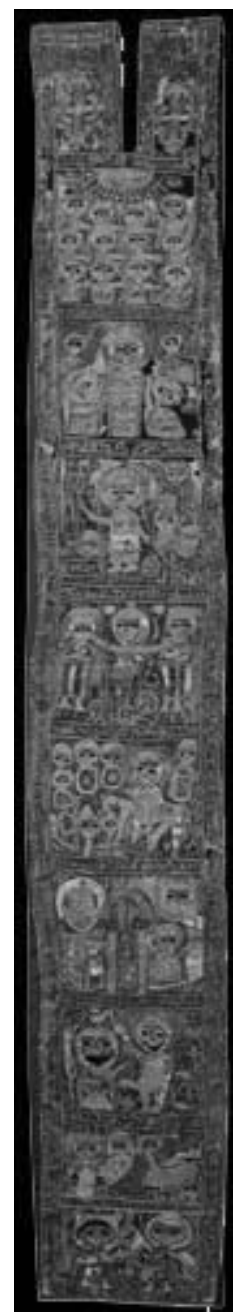

Fig. 1. The front of the stole.

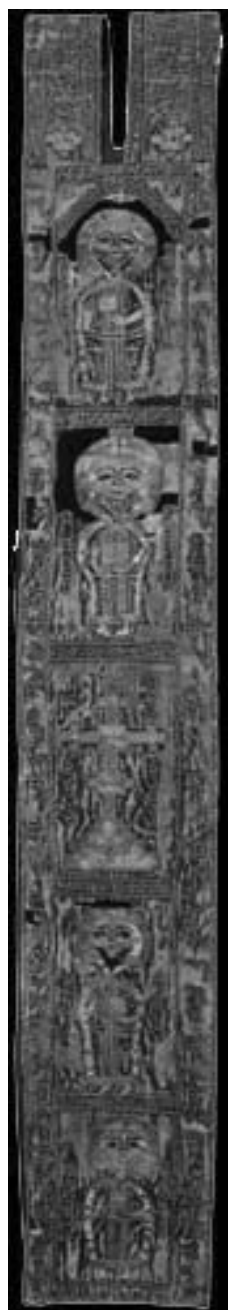

Fig. 2. The back of the stole.

The Metropolitan Museum of Art, Rogers Fund, 1914 (14.137) Photography, The Department of Textile Conservation, The Metropolitan Museum of Art, all rights reserved. 


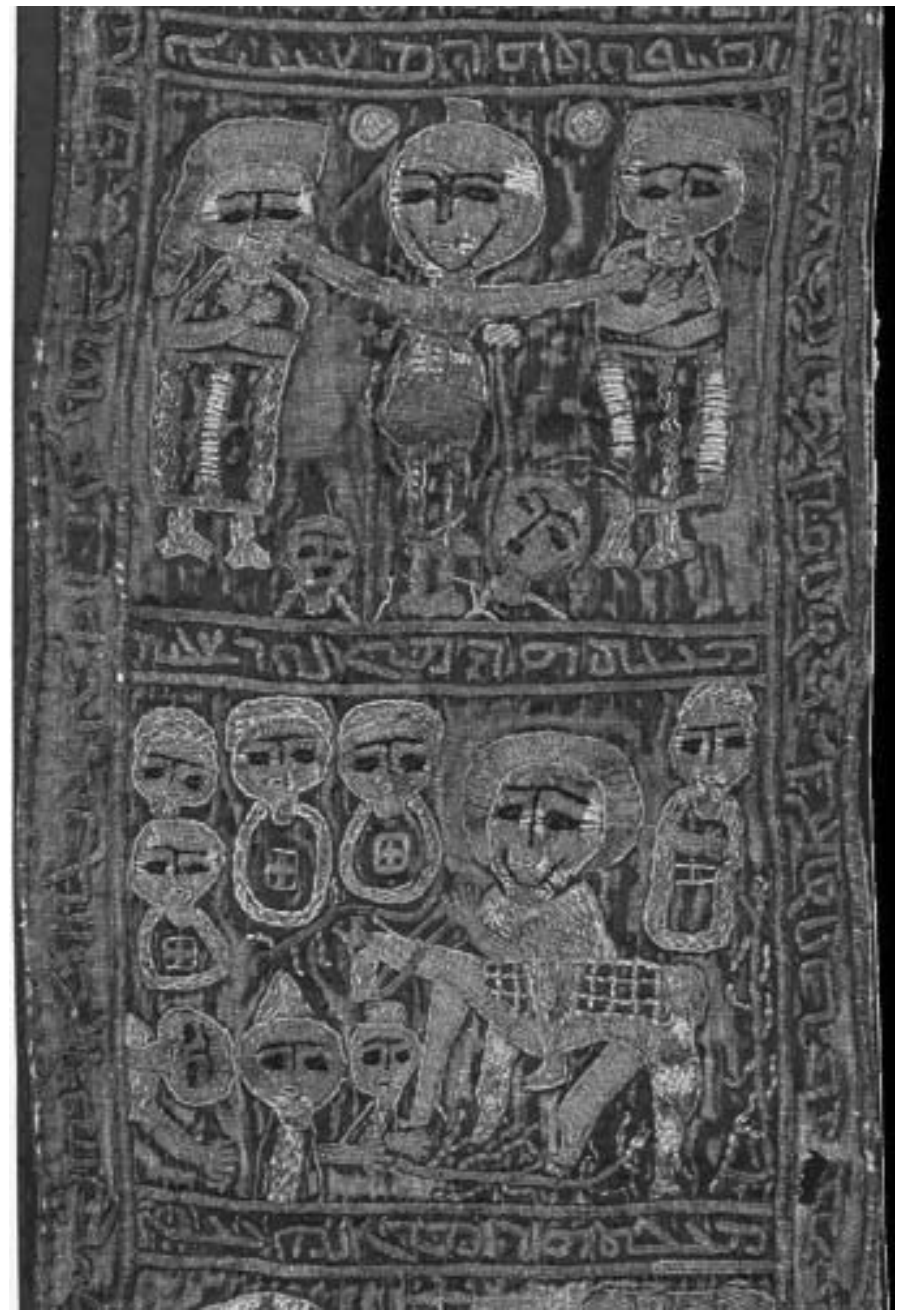

Fig. 3. 'Entry into Jerusalem' panel on the front of the stole.

The Metropolitan Museum of Art, Rogers Fund, 1914 (14.137) Photography, The Department of Textile Conservation, The Metropolitan Museum of Art, all rights reserved. 


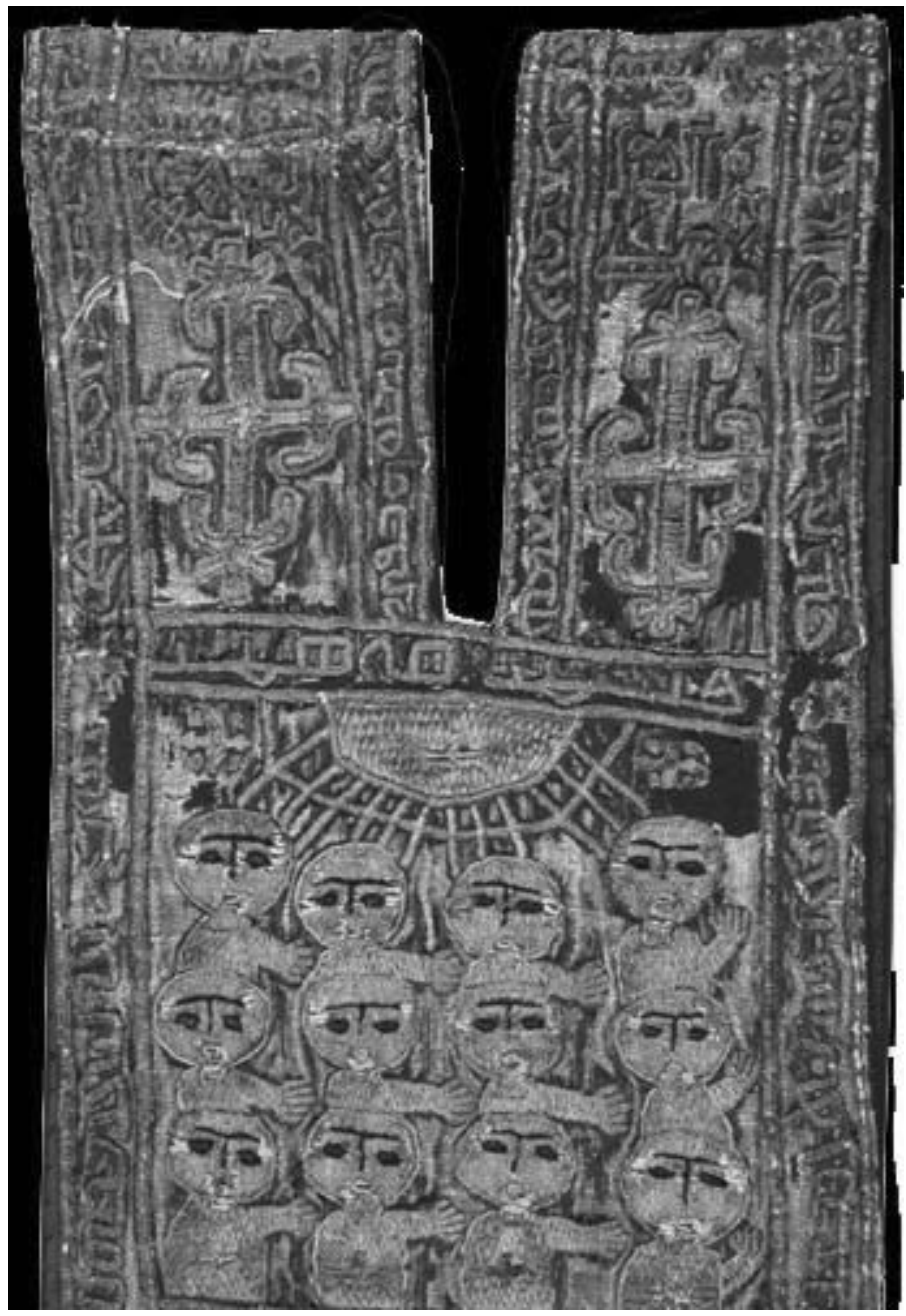

Fig. 4. 'Pentecost' panel on the front of the stole.

The Metropolitan Museum of Art, Rogers Fund, 1914 (14.137) Photography, The Department of Textile Conservation, The Metropolitan Museum of Art, all rights reserved. 


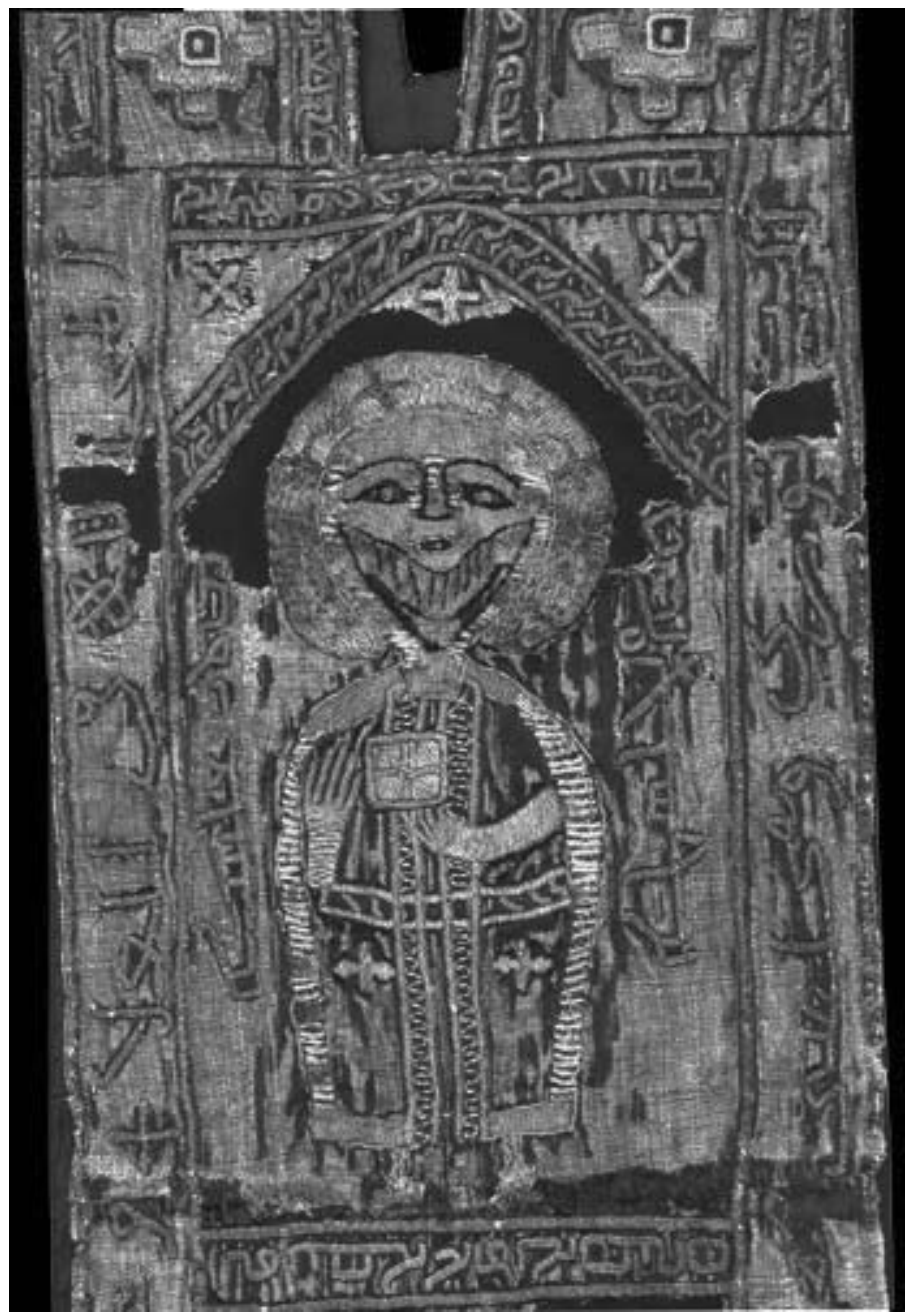

Fig. 5. An 'Evangelist' panel on the back of the stole.

The Metropolitan Museum of Art, Rogers Fund, 1914 (14.137) Photography, The Department of Textile Conservation, The Metropolitan Museum of Art, all rights reserved. 


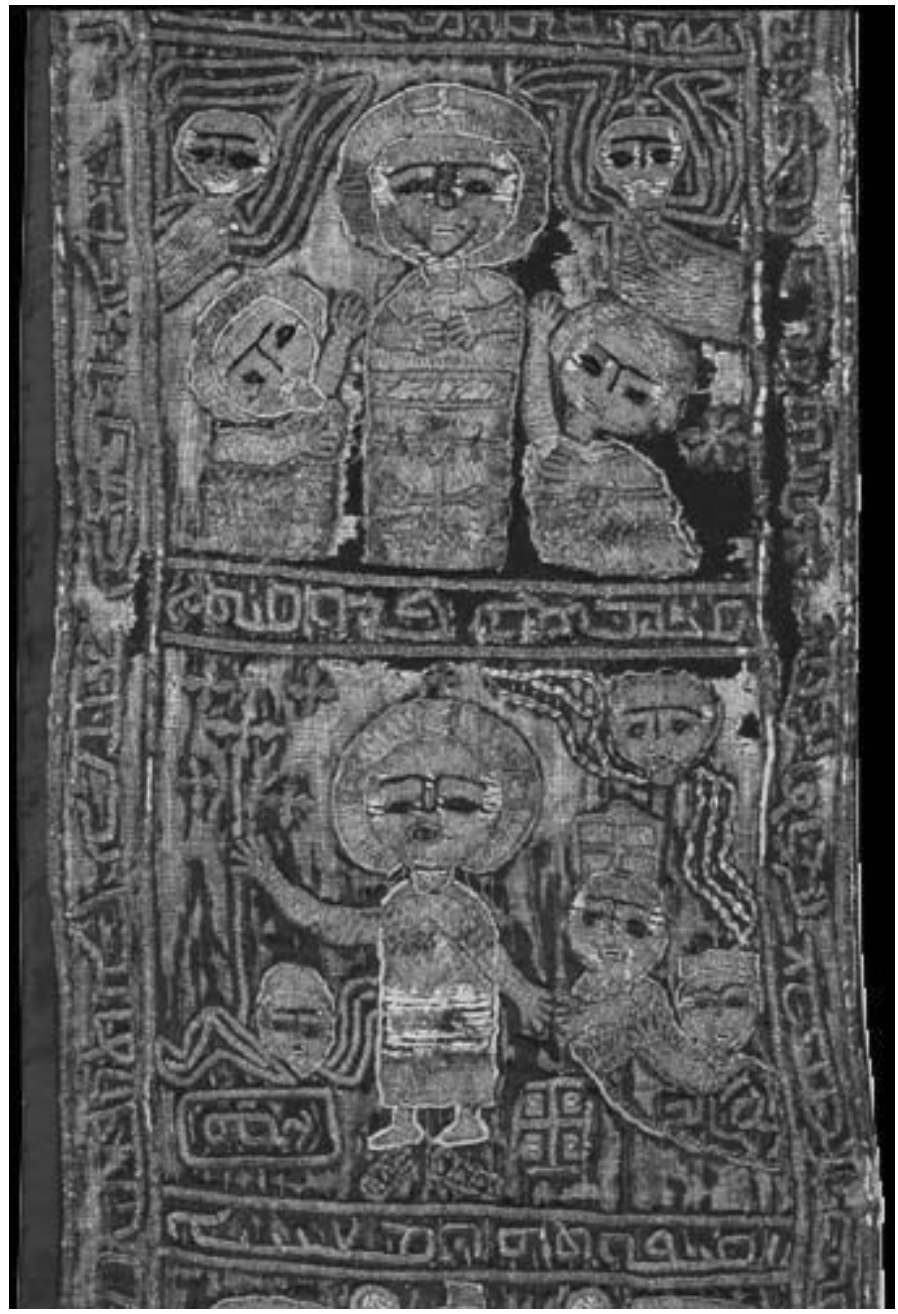

Fig. 6. The 'Resurrection' and 'Ascension' panels on the front.

The Metropolitan Museum of Art, Rogers Fund, 1914 (14.137) Photography, The Department of

Textile Conservation, The Metropolitan Museum of Art, all rights reserved. 


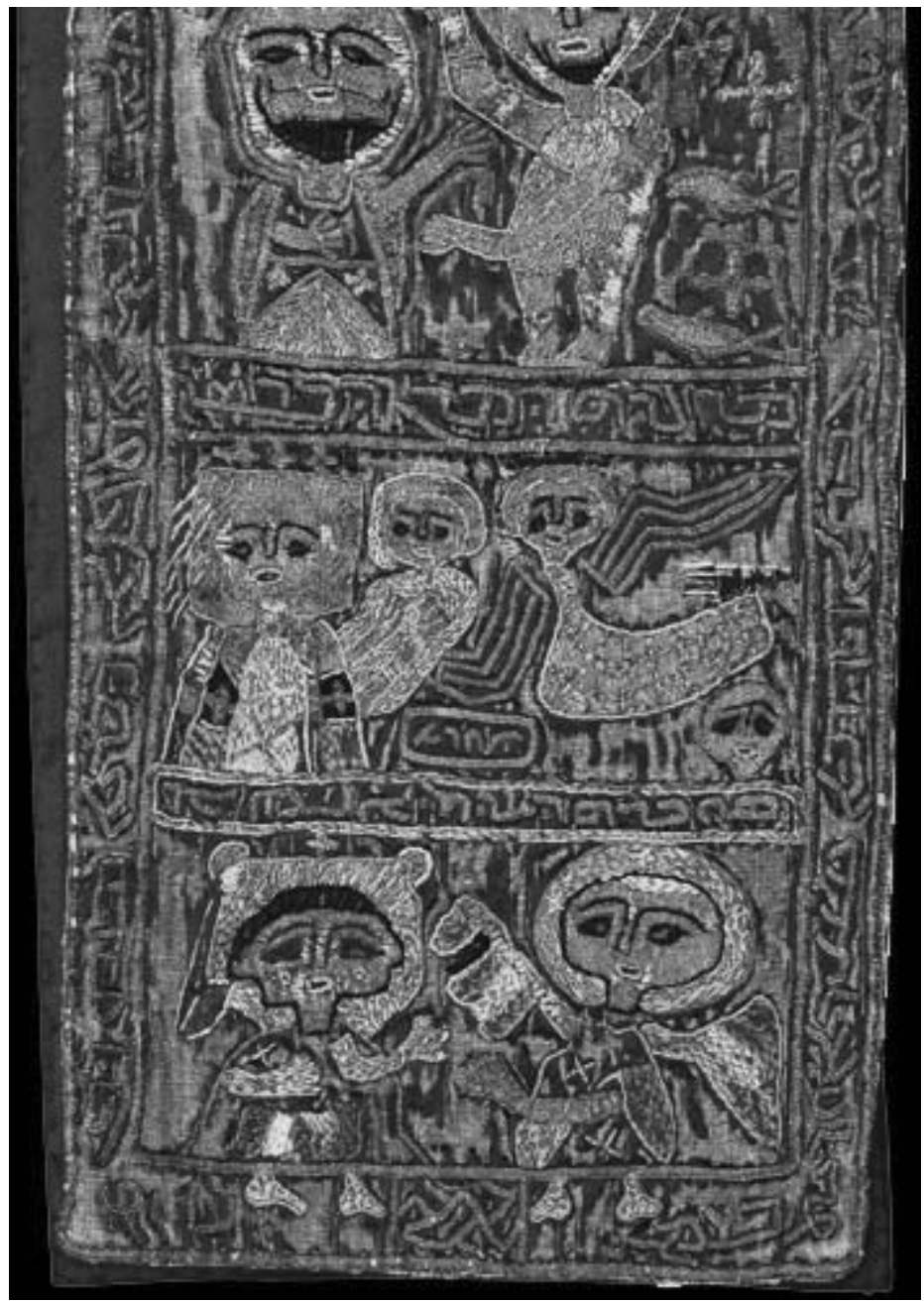

Fig. 7. The 'Annunciation' panel on the front.

The Metropolitan Museum of Art, Rogers Fund, 1914 (14.137) Photography, The Department of Textile Conservation, The Metropolitan Museum of Art, all rights reserved. 
